\title{
Delivering Primary Care to Homeless Persons: A Policy Analysis Approach to Evaluating the Options
}

\section{Prestation de soins de santé primaires pour les sans-abri : évaluation des options à l'aide d'une analyse des politiques}

\author{
5 \\ by S.E.D. SHORTT, MD, PHD \\ Department of Community Health and Epidemiology \\ Department of Family Medicine \\ Centre for Health Services and Policy Research \\ Queen's University, Kingston, $\mathrm{ON}$
}

STEPHEN HWANG, MPH, MD

Centre for Research on Inner City Health, St. Michael's Hospital,

Faculty of Medicine, Division of General Internal Medicine,

School of Public Health Sciences,

Department of Health Policy, Management, and Evaluation,

University of Toronto,

Toronto, ON

HEATHER STUART, PHD

Department of Community Health and Epidemiology,

Department of Psychiatry,

Queen's University,

Kingston, $\mathrm{ON}$ 
Delivering Primary Care to Homeless Persons: A Policy Analysis Approach to Evaluating the Options

MELANIE BEDORE, MPA

Centre for Health Services and Policy Research

Queen's University

Kingston, ON

NADIA ZURBA, MPA

Centre for Health Services and Policy Research

Queen's University

Kingston, ON

MARGARET DARLING, MLS

Centre for Health Services and Policy Research

Queen's University

Kingston, $\mathrm{ON}$

\begin{abstract}
Homeless persons are numerous, carry a significant burden of illness and face challenges in accessing care. A search of the literature revealed insufficient empirical sources to permit the use of standard systematic review methodology to determine the most effective way to deliver point-of-first-contact healthcare to homeless people. Instead, we used a policy analysis approach. We found that the dominant model of primary care in Canada performs poorly when assessed on 13 evaluation criteria. While there is variable performance on individual measures, the three alternative models - targeted standard facility/clinic site, fixed outreach site and mobile outreach service - all perform well. Our findings suggest that some factor other than performance on the specified measures, such as costs, feasibility, geographical fit or local preferences, should be used to choose a specific model. Our analysis clearly indicates that the status quo model of primary care is inadequate to meet the needs of homeless people.
\end{abstract}

\title{
Résumé
}

Les sans-abri sont nombreux, ils doivent surmonter de durs problèmes de santé et font face à des défis d'accessibilité quant aux soins de santé. Nos recherches dans la littérature nont pas permis d'amasser suffisamment de sources empiriques pour mener une revue systématique méthodologiquement acceptable afin de déterminer les façons les plus efficaces d'offrir des points d'accès de première ligne pour les sans-abri. Nous avons donc employé une méthode d'analyse des politiques. Nous avons découvert que, selon les 13 critères d'évaluation utilisés, le modèle actuel des soins de santé primaires au Canada présente un faible rendement. Bien que le rendement varie pour ce qui 
est des mesures individuelles, les trois autres modèles - établissements ou cliniques normales ciblées, points de contact fixes et points de contact mobiles - présentent un bon rendement. Les résultats laissent croire que des facteurs autres que le rendement des mesures particulières, tels que le coût, la faisabilité, la commodité géographique ou les préférences locales, devraient être employés afin de choisir un modèle particulier. Notre analyse indique clairement que le statu quo pour le modèle de soins primaires est inadéquat quant aux besoins des sans-abri.

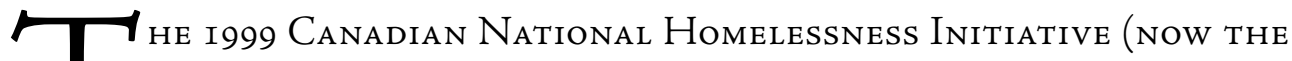 Homeless Partnering Strategy; HRSDC 2008) defined as homeless "any 1 person, family or household that has no fixed address or security of tenure."} How many people fall within this definition is unknown, particularly since "rough sleepers" (persons on the streets) and "couch surfers" (individuals chronically staying with others) are almost impossible to enumerate. However, the 2001 Census found that 14,145 persons were using shelters at any given time in Canada; by the 2006 Census, that number had risen to 19,630 (Statistics Canada 2002, 2008). Males, aged 35 to 64 years, were the most common subgroup within this population, followed by males, aged 15 to 34 years (Statistics Canada 2002). Data from Toronto and Ottawa revealed that families constitute a significant portion of shelter users, occupying $42 \%$ and $35 \%$ of shelter beds in each city, respectively (Hwang 2001). Aboriginal people are over-represented in the homeless population; in Toronto, they accounted for $2 \%$ of the total population in 1999 but $25 \%$ of the homeless population (Begin et al. 1999).

It is difficult to describe with precision the health problems of homeless persons, in part because of the heterogeneity of this population across geographical regions (Lindsey 1995). A number of studies have attempted to document the health conditions encountered by homeless populations in specific facilities or regions (Nuttbrock et al. 2003; Blewett et al. 1999; Spanowicz et al. 1998; Plescia et al. 1997). It is apparent that certain conditions, such as trauma, respiratory infections, dermatological conditions, mental illness and substance abuse, are strongly associated with homelessness. Almost all other forms of chronic illness - such as diabetes, osteoarthritis and high blood pressure - that are common in both housed and homeless populations are made worse by homelessness because of inability to receive regular care or to selfmanage the condition appropriately. Moreover, diseases such as HIV/AIDS or tuberculosis, which require aggressive treatment, undoubtedly carry a much less favourable prognosis for homeless persons than for the general population. One indicator of the severity of these morbidities is the much higher rate of premature death among homeless persons compared to the housed population (Roy et al. 1998; Hwang 2000). 
Despite this substantial burden of illness, homeless persons face a variety of barriers to receiving appropriate healthcare. A significant obstacle to accessing care in Canada is the absence of a valid entitlement document, i.e., a provincial health card (Hwang et al. 2000). Homeless people may be unable to afford supplies or medications that are not covered under provincial healthcare plans (OMR 1996). Physicians' offices are seldom located in areas where homeless people tend to congregate and are usually open only during regular office hours, posing significant transportation and scheduling challenges (Gelberg et al. 2002; Kurtz et al. 2005). Homeless people may encounter psychological barriers, such as fear of care refusal (Bunce 2000) or feelings of stigmatization by healthcare providers (Gelberg et al. 2004). Finally, homeless individuals may delay seeking medical care because other needs, such as securing food and shelter, are more critical to their daily survival.

Homeless persons are numerous, carry a significant burden of illness and face challenges in accessing care. This paper asks the question: What is the most effective way to deliver point-of-first-contact or primary healthcare to homeless persons? A search of the literature revealed insufficient empirical sources to answer the question using standard systematic review methodology. Instead, as discussed below, we used a policy analysis approach.

\section{Data Retrieval}

A structured literature search was conducted for English-language publications from 1990 to 2006 in the following databases: Medline, Embase, Cinahl and the Cochrane Library, Social Services Abstracts, Social Sciences Citation Index, Social Sciences Index, Sociological Abstracts, CBCA, Canadian Newsstand, JStor, Readers' Guide and PAIS International. Throughout the study period a "My NCBI Alert" was used to deliver new search results from Medline (PubMed) on a weekly basis, and periodic update searches were conducted in the other databases.

Search strategies for each database were developed using natural-language keywords and controlled vocabulary terms specific to each database. Three related searches covered the following topics: primary healthcare services for homeless persons; impact of primary healthcare services for homeless persons; and health problems of homeless persons.

Additional sources were identified through a manual search of bibliographies and references, and the World Wide Web was searched using Google (advanced search mode) to identify grey literature, organizations involved in providing services to the homeless and examples of programs providing primary care services to homeless persons. All references were recorded in a database created using Reference Manager 11. 


\section{S.E.D. Shortt et al.}

\section{Analysis}

The search revealed that the literature, though extensive, was largely descriptive. There was insufficient empirical data to conduct a systematic review (Bravata et al.2005) of primary care delivery methods. There were also too few robust evaluations of primary care programs for homeless persons to permit a narrative synthesis (Dixon-Woods et al. 2004). However, the existing literature did lend itself to a policy analysis approach. Such an approach examines the relevance of specific research findings to a policy issue, weighs the evidence and constructs a logical case about the utility of specific policy options for addressing the issue in light of predetermined policy objectives (Aday and Begley 1993). The key steps in policy analysis are articulating a broad policy goal; dividing that goal into measurable objectives; selecting evaluation criteria by which the attainment of objectives will be assessed; and judging how various policy options are most likely to perform when measured by these predetermined evaluation criteria. In the absence of definitive empirical evidence about the various policy options, this judgment process necessarily represents the informed opinion of the policy analysis team.

\section{Results}

The a priori policy goal is to ensure use of the most effective way to provide point-offirst-contact healthcare to homeless persons. Measurable objectives that support this goal may be taken from the seven defining attributes of appropriate primary healthcare recently identified by the Canadian Institute for Health Information through a comprehensive consultation process (CIHI 2006). These attributes correspond closely to the seven desirable system-level service delivery attributes identified by the Working Group on Homeless Health Outcomes for the United States Department of Health and Human Services (US Bureau of PHC 1996). The objectives are:

1. Ensuring access to primary healthcare through a regular primary healthcare provider.

2. Enhancing the population orientation of primary healthcare - for example, health promotion strategies that engage and mobilize the community.

3. Providing comprehensive whole-person care that addresses physical, social and psychological dimensions.

4. Enhancing an integrated approach to $24 / 7$ access.

5. Strengthening the quality of primary healthcare.

6. Building patient-centred care, that is, taking into account the patient's desire for information and decision-making in an empathetic and open manner.

7. Promoting continuity through integration and coordination. 
Delivering Primary Care to Homeless Persons: A Policy Analysis Approach to Evaluating the Options

To ensure that the evaluation criteria for each of these objectives are specific to the needs of homeless persons, it is necessary to consult the literature describing the barriers that this disadvantaged population faces in obtaining primary care. That is, evaluation criteria are the adaptations to the delivery and structure of care necessary to counter the barriers. Such adaptations were summarized at the 1998 National Symposium on Homeless Research in the United States (McMurray-Avila et al. 1998) and may be inferred from the many discussions of barriers to care faced by homeless persons (Bunce 2000; Gelberg et al. 2004; McMurray-Avila et al. 1998; OWHC 2002). The criteria deemed most relevant are listed in Table 1.

TABLE 1. Evaluation criteria for homeless primary care

\begin{tabular}{|c|c|c|}
\hline Goal & Objectives & Evaluation criteria \\
\hline \multirow[t]{7}{*}{$\begin{array}{l}\text { To enhance the health of } \\
\text { homeless persons through } \\
\text { the provision of optimal } \\
\text { primary care }\end{array}$} & $\begin{array}{l}\text { Ensuring access to primary healthcare } \\
\text { through a regular primary healthcare } \\
\text { provider }\end{array}$ & $\begin{array}{l}\text { - Entitlement documents not required for } \\
\text { care or for ancillary services } \\
\text { - Service available at venues likely to suit } \\
\text { homeless persons }\end{array}$ \\
\hline & $\begin{array}{l}\text { Enhancing the population orientation of } \\
\text { primary healthcare }\end{array}$ & $\begin{array}{l}\text { - Collaboration with public health } \\
\text { authorities on harm reduction strategies }\end{array}$ \\
\hline & $\begin{array}{l}\text { Providing comprehensive whole-person } \\
\text { care }\end{array}$ & $\begin{array}{l}\text { - Multidisciplinary team care } \\
\text { - Established referral routes for specialty } \\
\text { services } \\
\text { - Social work assistance available for } \\
\text { benefit entitlement, housing }\end{array}$ \\
\hline & $\begin{array}{l}\text { Enhancing an integrated approach to } \\
24 / 7 \text { access }\end{array}$ & $\begin{array}{l}\text { - Service available at times likely to suit } \\
\text { homeless persons } \\
\text { - Evidence of reduced emergency room } \\
\text { use }\end{array}$ \\
\hline & $\begin{array}{l}\text { Strengthening the quality of primary } \\
\text { healthcare }\end{array}$ & $\begin{array}{l}\text { - Special expertise in areas germane } \\
\text { to the clinical conditions of homeless } \\
\text { persons, e.g., substance abuse, sexually } \\
\text { transmitted diseases }\end{array}$ \\
\hline & Building patient-centred care & $\begin{array}{l}\text { - User involvement in service planning } \\
\text { and operation }\end{array}$ \\
\hline & $\begin{array}{l}\text { Promoting continuity through integration } \\
\text { and coordination }\end{array}$ & $\begin{array}{l}\text { - Appropriate access to electronic medical } \\
\text { records by multiple providers } \\
\text { - Mechanisms to contact patients } \\
\text { - Hospital liaison for planning discharge }\end{array}$ \\
\hline
\end{tabular}

What are the options for delivering primary care to homeless persons? The literature suggests four broad options, distinguished largely by the location at which care is delivered, but also by associated organizational features: the status quo based on 
independent family doctors' offices and three models directed specifically at homeless clients - standard facility/clinic site, fixed outreach site and mobile outreach service. Although the voluminous literature on homelessness and health includes many brief descriptions of local interventions, no single paper provides a sufficiently generic experience upon which broad generalizations can be based. However, from the diverse papers available on each specific model of care, it is possible to extract common characteristics, which can then be reassembled into an archetypal description of that model. The selection of sources is purposive but, for this essentially illustrative intent, need not be either systematic or exhaustive. The resulting description can be moved beyond a synthetic "typical" composite to capture the model's full potential by the addition of innovative but successful features found in only a few sites. The idealized composite picture that emerges may then serve as a paradigm of that model of care when assessing potential effectiveness. A brief description of each model follows.

\section{Primary care status quo}

Many types of practices can be found in Canada, but physician-centred solo and small group practices are the norm. In the 2001 National Family Physician Workforce Survey, $73 \%$ of family doctors reported that private offices were their main practice setting. Solo practice is more common in inner cities, with $46 \%$ of family doctors in these areas reporting solo practice, compared to $19 \%$ in isolated or remote areas. Between 1989 and 2000, the number of physicians reporting that they operate "officeonly" practices - meaning they did not make house calls, provide hospital or nursing home care, work in emergency departments or provide obstetrical services - rose from $14 \%$ to $24 \%$. Most family doctors in Canada are paid on a fee-for-service basis by submitting bills to provincial or territorial health insurance plans for each service provided. Alternative payment structures accounted for $11 \%$ of total clinical payments in 2000-2001 but are increasing (CIHI 2003). In 2001, 94\% of Canadians aged 15 and over received care from a family physician, commonly during regular office hours. However, almost one in five of those who sought "first contact" services in 2001 had difficulty accessing care at some point in that year (CIHI 2003). The 2004 National Physician Survey found that only $20 \%$ of practices were open to new patients, and a Decima poll reported that five million Canadians over 18 years of age were unable to find a family doctor in the 12 months preceding the survey (CFPC 2004).

A recently described typology of Canadian primary care models summarized the status quo under the term professional contact model. This model aims to facilitate a care-seeking person's ability to make first contact with the healthcare system. Individuals usually travel to the physician's office, a single location where the physician may practise alone or in a group. Such physicians are rarely associated with other health professionals and are commonly paid on a fee-for-service basis. With the profes- 
Delivering Primary Care to Homeless Persons: A Policy Analysis Approach to Evaluating the Options

sional contact model, there is no tool beyond patient loyalty to ensure long-term continuity of care, and there is no formal mechanism to ensure integration with other health services. The model facilitates accessibility and responsiveness to patients but performs poorly in terms of effectiveness, productivity, equity and quality (CHSRF et al. 2003).

\section{Standard facility or clinic site}

Descriptions are available in the literature of standard facilities or clinic sites exclusively dedicated to serving homeless persons in Miami (Fournier et al. 1993), New York (Morrow et al. 1992) and Los Angeles (Gelberg et al. 1996); some additional details on the operation of such initiatives were drawn from other published sources. Such clinics may originate as a charitable and volunteer initiative, but generally are affiliated with an institution such as a hospital or community health centre. Academic links providing training for nursing and medical students are common. Care is delivered by multidisciplinary teams, with non-clinical services available from social workers or legal staff. Close connections are maintained with social service agencies and public health units to which clients can be referred. A hospital affiliation facilitates referrals to specialists, but some specialty care may be available on site.

Clinics are often found near shelters, and in some cases outreach visits to these sites may take place. Typically, clinics have both daytime and evening hours of operation. The emphasis is on immediate care for acute illnesses, with the hope that persons requiring more complex care can be successfully integrated into the general health system. Screening and health education are common elements of care (Edwards et al. 1998; Macnee et al. 1996). Care is provided without charge, as are a limited range of medications and laboratory tests. More sophisticated testing may be available from affiliated organizations. A significant number of patient encounters are repeat visits. A broad array of clinical services available in a timely manner may reduce emergency room use.

\section{Fixed outreach model}

A composite picture of fixed outreach programs can be constructed from descriptions of initiatives in New York (Plescia et al. 1997), Boston (Kline and Saperstein 1992), New Orleans (Steele and O'Keefe 2001), California (Fiore 1995) and Ohio (DiMarco 2000), with additional details extracted from other sources. "Outreach" in this model refers to care that is provided in non-traditional settings frequented by, or convenient to, homeless persons, in the absence of which such individuals would be unlikely to access services (Morse et al. 1996). The care may be delivered at schools (Berti et al. 2001; Nabors et al. 2004), in community drop-in centres (Cunnane et al. 1995; Reuler 1991) or in transitional housing settings (Rog et al. 1995), but the most common location is at homeless shelters. Regularly scheduled sessions are held at these 
venues and are staffed predominantly by nurses but with physicians, social workers and counsellors on the team as well. Care is delivered without charge, and often some medications are also available free of charge to patients. Mechanisms may be in place to expedite registration for benefit programs for those patients who are eligible.

Services include acute care for minor and chronic conditions, preventive care and education, and referral to other providers or agencies. Outreach clinics usually have good linkages with many other health and social agencies, including public health units to which patients can be referred; referrals to community clinics and specialty care at nearby hospitals are common. There may be formal administrative and funding ties between the outreach clinic and established healthcare facilities in the region. Brief clinical records are commonly kept, providing the basis for activity reports that focus on types and volume of services but only rarely on outcomes (Tischler et al. 2002; Bradford et al. 2005; Cunningham et al. 2005). Increasingly, these records are kept in electronic format (Blewett et al. 1999). In a large number of cases patients are seen on only one occasion, but a small number of patients become regular users of these sites. By becoming frequent users with attendant documentation, such individuals assist the clinics accomplish what is often their main goal in addition to the provision of immediate care: helping individuals reintegrate into mainstream care programs by eventually transferring care to more traditional care venues.

\section{Mobile outreach service model}

Program descriptions from New York (Redlener and Redlener 1994) and Georgia (Tollett and Thomas 1995; Testani-Dufour et al. 1996), supplemented with details from other programs, provide sufficient information to construct a composite picture of the mobile outreach service model. Mobile services operate from vehicles of various descriptions at sites convenient to homeless persons, such as at shelters or on the streets. Often the units visit their sites on a regular schedule so that clients can anticipate their arrival. The target population may be specialized, such as youth (Auerswald et al. 2006) or persons with mental illness (Farrell et al. 2005; Morris and Warnock 2001), or it may focus on anyone without a home. Visits may be scheduled or offered on a walk-in basis, and there is no cost to the user. The services provided may be determined by a preliminary needs assessment and modified on the basis of subsequent client input. Space may limit the range and volume of services available, but common services include diagnosis, including the performance of basic laboratory tests; the treatment of acute and chronic conditions, for which a limited range of medications may be dispensed; screening and prevention activities; educational interventions; and referrals to other community agencies or specialized care. These services are provided by a team weighted towards nurses but including a variable physician pres- 
ence and other providers, such as social workers. Point-of-contact electronic records may be linked to a central database, and hand-held devices may be used to enter new encounter data (Buck et al. 2005; Bunschoten 1994). Success may be measured by such programs on the basis of tabulations of the numbers of client encounters, repeat visits or referrals, or by surveying clients and providers. Sponsors may include independent charitable organizations or healthcare institutions such as hospitals; extensive collaboration with other agencies is common. Costs relative to other delivery methods are seldom reported because they are challenging to assess and may depend on location or funding source (Wray et al. 1999).

Based on the data presented above, it is now possible, as shown in Table 2, to apply the evaluation criteria to the four options. The status quo performs poorly by all but one of the 13 evaluation criteria. While there is variable performance on individual measures, the remaining three models all perform well. This finding implies that some factor other than performance on the specified measures should be used to choose a specific model. Such factors might include comparative costs, feasibility for staffing, geographic distribution of the population served or local preferences.

\section{Conclusion}

Primary care in Canada has witnessed the appearance of a number of new models of payment and organization over the last two decades. Some of these may be better suited to meeting the needs of homeless persons than others, but the literature as yet contains no evidence to support this assertion. Indeed, the lack of published research on Canadian programs for the care of homeless persons was a striking finding in this project. To better understand this deficit, a snowballing technique was used to identify 42 primary care programs targeting homeless individuals across Canada. All were approached to take part in key-informant interviews, and 18 agreed. None was able to provide published or unpublished program descriptions or evaluations. There was a consensus among informants that the programs lacked the evaluation skills to create such documents and that any costs associated with creating documents would reduce already inadequate clinical care budgets.

It is easy to assume that a health system such as Canada's, which provides universal first-dollar coverage, meets the health needs of homeless persons. But the concept of "horizontal equity" that underlies the system - equal needs receive equal resources - fails to appreciate the different and far greater needs present in vulnerable groups. These populations require a system that incorporates "vertical equity," that is, the capacity to meet unequal needs with unequal resources. The disproportionate burden of illness borne by the homeless population constitutes a dramatic inequality of health need, yet in comparison to specialized services designed to meet these needs, the cur- 


\section{S.E.D. Shortt et al.}

rent model of primary care in Canada is inadequate. To ignore this inadequacy by failing to provide specialized care is to permit the operation of what has been termed the "inverse care law," which states that "the availability of good medical care tends to vary inversely with the need for it in the population served" (Hart 1971: 405). If, as has been proposed, a measure of any health system's merit is the way in which it treats its most vulnerable citizens (Brownell et al. 2001), Canada's primary care system must urgently address the health needs of the homeless population.

TABLE 2. Evaluation of four models

\begin{tabular}{|c|c|c|c|c|}
\hline Evaluation criteria & $\begin{array}{l}\text { Status } \\
\text { quo } \\
\text { model }\end{array}$ & $\begin{array}{l}\text { Standard } \\
\text { facility/ } \\
\text { clinic site }\end{array}$ & $\begin{array}{l}\text { Fixed } \\
\text { outreach } \\
\text { site }\end{array}$ & $\begin{array}{l}\text { Mobile } \\
\text { outreach } \\
\text { service }\end{array}$ \\
\hline $\begin{array}{l}\text { Entitlement documents not required for } \\
\text { healthcare or for ancillary services }\end{array}$ & poor & excellent & excellent & excellent \\
\hline $\begin{array}{l}\text { Service available at venues likely to suit } \\
\text { homeless persons }\end{array}$ & poor & well & excellent & excellent \\
\hline $\begin{array}{l}\text { Collaboration with public health authorities } \\
\text { on harm reduction strategies }\end{array}$ & poor & well & adequate & adequate \\
\hline Multidisciplinary team care & poor & excellent & excellent & excellent \\
\hline $\begin{array}{l}\text { Established referral routes for specialty } \\
\text { services }\end{array}$ & excellent & excellent & excellent & adequate \\
\hline $\begin{array}{l}\text { Social work assistance available for benefit } \\
\text { entitlement, housing }\end{array}$ & poor & excellent & excellent & well \\
\hline $\begin{array}{l}\text { Service available at times likely to suit } \\
\text { homeless persons }\end{array}$ & poor & well & adequate & excellent \\
\hline Evidence of reduced emergency room use & poor & adequate & unknown & unknown \\
\hline $\begin{array}{l}\text { Special expertise in areas germane to the } \\
\text { clinical conditions of homeless persons, } \\
\text { e.g., substance abuse, sexually transmitted } \\
\text { diseases }\end{array}$ & poor & excellent & excellent & well \\
\hline $\begin{array}{l}\text { User involvement in service planning and } \\
\text { operation }\end{array}$ & poor & poor & poor & adequate \\
\hline $\begin{array}{l}\text { Appropriate access to electronic medical } \\
\text { records by multiple providers }\end{array}$ & poor & well & adequate & well \\
\hline Mechanisms to contact patients & poor & well & fair & fair \\
\hline Hospital liaison for planning discharge & poor & unknown & poor & poor \\
\hline
\end{tabular}

Assessment scale: poor-fair-adequate-well-excellent. 
Delivering Primary Care to Homeless Persons: A Policy Analysis Approach to Evaluating the Options

\section{ACKNOWLEDGEMENTS}

This study was made possible by an operating grant from the Canadian Institutes of Health Research.

Correspondence may be directed to: Sam Shortt, MPA, MD, PhD, Centre for Health Services and Policy Research, Abramsky Hall, Queen's University, Kingston, ON K7L 3N6; tel.: 613-5336387; e-mail: seds@queensu.ca.

\section{REFERENCES}

Aday, L.A. and C.E. Begley. 1993. Evaluating the Medical Care System: Effectiveness, Efficiency, and Equity. Ann Arbor, MI: Health Administration Press.

Auerswald, C.L., E. Sugano, J.M. Ellen and J.D. Klausner. 2006 (March). “Street-Based STD Testing and Treatment of Homeless Youth Are Feasible, Acceptable and Effective." Journal of Adolescent Health 38(3): 208-12.

Begin, P., L. Casavant, N.M. Chenier and J. Dupuis. 1999. Homelessness 1999. Retrieved June 23, 2008. <http://www.parl.gc.ca/information/library/PRBpubs/prb991-e.htm>.

Berti, L.C., S. Zylbert and L. Rolnitzky. 2001 (September). "Comparison of Health Status of Children Using a School-Based Health Center for Comprehensive Care." Journal of Pediatric Health Care 15(5): 244-50.

Blewett, D.R., G.O. Barnett and H.C. Chueh. 1999."Experience with an Electronic Health Record for a Homeless Population." Proceedings of the American Medical Informatics Association Symposium 1999: 481-85.

Bradford, D.W., B.N. Gaynes, M.M. Kim, J.S. Kaufman and M. Weinberger. 2005 (August). "Can Shelter-Based Interventions Improve Treatment Engagement in Homeless Individuals with Psychiatric and/or Substance Misuse Disorders? A Randomized Controlled Trial." Medical Care 43(8): 763-68.

Bravata, D.M., K.M. McDonald, K.G. Shojania, V. Sundaram and D.K. Owens. 2005 (June 21).

"Challenges in Systematic Reviews: Synthesis of Topics Related to the Delivery, Organization, and Financing of Health Care." Annals of Internal Medicine 142(12 Pt 2): 1056-65.

Brownell, M.D., N.P. Roos and L.L. Roos. 2001 (March)."Monitoring Health Reform: A Report Card Approach." Social Science and Medicine 52(5): 657-70.

Buck, D.S., D. Rochon and J.P. Turley. 2005 (September). "Taking It to the Streets: Recording Medical Outreach Data on Personal Digital Assistants." Computers, Informatics, Nursing 23(5): 250-55.

Bunce, D. 2000 (May 10). "Problems Faced by Homeless Men in Obtaining Health Care." Nursing Standard (Royal College of Nursing of Great Britain) 14(34): 43-45.

Bunschoten, B. 1994 (April). "Homeless Projects Show Value of Electronic Records." Health Data Management 2(3): 51-54.

Canadian Health Services Research Foundation (CHSRF), P.A. Lamarche, M. Beaulieu, R. Pineault, A. Contandriopoulos and J.L.H.J. Denis. 2003. Choices for Change: The Path for Restructuring Primary Healthcare Services in Canada. Retrieved June 23, 2008. <http://www.chsrf. $\mathrm{ca} /$ final_research/commissioned_research/policy_synthesis/pdf/choices_for_change_e.pdf >. 
Canadian Institute for Health Information (CIHI). 2003. Health Care in Canada, 2003. Retrieved June 23, 2008. <http://secure.cihi.ca/cihiweb/products/hcic2003_e.pdf>.

Canadian Institute for Health Information (CIHI). 2006. "Pan-Canadian Primary Health Care Indicator Development Project." Pan-Canadian Primary Health Care Indicators: Report 1, v. 1 \& 2. Retrieved June 23, 2008. <http://www.cihi.ca/cihiweb/dispPage.jsp?cw_page=GR_1489_E >. College of Family Physicians of Canada (CFPC). 2004 (November). Family Medicine in Canada: A Vision for the Future 2004. Conference. Mississauga, ON: Author. Retrieved June 23, 2008. $<$ http://www.cfpc.ca/local/files/Communications/Health\%20Policy/FAMILY_MEDICINE_ IN_CANADA_English.pdf>.

Cunnane, E., W. Wyman, A. Rotermund and R. Murray. 1995 (April)."Innovative Programming in a Community Service Center." Community Mental Health Journal 31(2): 153-61.

Cunningham, C.O., S. Shapiro, K.M. Berg, G. Sacajiu, G. Paccione and J.L. Goulet. 2005 (February). "An Evaluation of a Medical Outreach Program Targeting Unstably Housed HIVInfected Individuals." Journal of Health Care for the Poor and Underserved 16(1): 127-38.

DiMarco, M.A. 2000 (January)."Faculty Practice at a Homeless Shelter for Women and Children." Holistic Nursing Practice 14(2): 29-37.

Dixon-Woods, M., S. Agarwal, B. Young, D. Jones and A. Sutton. 2004. "Integrative Approaches to Qualitative and Quantitative Evidence." National Institute for Health and Clinical Excellence. Retrieved June 23, 2008. <http://www.nice.org.uk:80/niceMedia/pdf/Integrative_approaches_ evidence.pdf $>$.

Edwards, J.B., A. Kaplan, J.T. Barnett and C.L. Logan. 1998 (January). "Nurse-Managed Primary Care in a Rural Community. Outcomes of Five Years of Practice." Nursing and Health Care Perspectives 19(1): 20-25.

Farrell, S.J., J. Huff, S.A. MacDonald, A. Middlebro and S. Walsh. 2005 (December). "Taking It to the Street: A Psychiatric Outreach Service in Canada." Community Mental Health Journal 41(6): 737-46.

Fiore, D.C. 1995 (December). "A Homeless Shelter Medical Clinic Organized and Staffed by Family Practice Residents." Western Journal of Medicine 163(6): 537-40.

Fournier, A.M., A. Perez-Stable and P.J. Greer Jr. 1993 (December 8)."Lessons from a Clinic for the Homeless. The Camillus Health Concern." Journal of the American Medical Association 270(22): 2721-24.

Gelberg, L., C.H. Browner, E. Lejano and L. Arangua. 2004. "Access to Women's Health Care: A Qualitative Study of Barriers Perceived by Homeless Women." Women and Health 40(2): 87-100. Gelberg, L., B.H. Doblin and B.D. Leake. 1996 (March). "Ambulatory Health Services Provided to Low-Income and Homeless Adult Patients in a Major Community Health Center." Journal of General Internal Medicine 11(3): 156-62.

Gelberg, L., B. Leake, M.C. Lu, R. Andersen, A.M. Nyamathi, H. Morgenstern and C. Browner. 2002 (November). "Chronically Homeless Women's Perceived Deterrents to Contraception." Perspectives on Sexual and Reproductive Health 34(6): 278-85.

Hart, J.T. 1971 (February 27). “The Inverse Care Law." Lancet 1(7696): 405-12.

Human Resources and Social Development Canada (HRSDC). 2008. Homelessness Partnering Strategy. Retrieved June 23, 2008. < http://www.homelessness.gc.ca/about_us/understanding_ homelessness_e.asp>. 
Delivering Primary Care to Homeless Persons: A Policy Analysis Approach to Evaluating the Options

Hwang, S.W. 2000 (April 26)."Mortality among Men Using Homeless Shelters in Toronto, Ontario." Journal of the American Medical Association 283(16): 2152-57.

Hwang, S.W. 2001. "Homelessness and Health." Canadian Medical Association Journal 164(2): 229-33.

Hwang, S.W., P.M. Windrim, T.J. Svoboda and W.F. Sullivan. 2000 (July 25). "Physician Payment for the Care of Homeless People." Canadian Medical Association Journal 163(2): 170-71.

Kline, E.N. and A.B. Saperstein. 1992 (December). "Homeless Women. The Context of an Urban Shelter." Nursing Clinics of North America 27(4): 885-99.

Kurtz, S.P., H.L. Surratt, M.C. Kiley and J.A. Inciardi. 2005 (May)."Barriers to Health and Social Services for Street-Based Sex Workers." Journal of Health Care for the Poor and Underserved 16(2): 345-61.

Lindsey, A.M. 1995. "Physical Health of Homeless Adults." Annual Review of Nursing Research 13: 31-61.

Macnee, C.L., J.C. Hemphill and J. Letran. 1996. "Screening Clinics for the Homeless: Evaluating Outcomes." Journal of Community Health Nursing 13(3): 167-77.

McMurray-Avila, M., L. Gelberg, W.R. Breakey and the National Symposium on Homelessness Research. 1998. "1. Balancing Act: Clinical Practices That Respond to the Needs of Homeless People." Retrieved June 23, 2008. <http://aspe.hhs.gov/progsys/homeless/symposium/8-Clinical. htm $>$.

Morris, D.W. and J.K. Warnock. 2001 (August)."Effectiveness of a Mobile Outreach and Crisis Services Unit in Reducing Psychiatric Symptoms in a Population of Homeless Persons with Severe Mental Illness." Journal of the Oklahoma State Medical Association 94(8): 343-46.

Morrow, R., J.L. Halbach, C. Hopkins, C. Wang, L.A. Shortridge. 1992 (May). “A Family Practice Model of Health Care for Homeless People: Collaboration with Family Nurse Practitioners." Family Medicine 24(4): 312-26.

Morse, G.A., R.J. Calsyn, J. Miller, P. Rosenberg, L. West and J. Gilliland. 1996 (June). “Outreach to Homeless Mentally Ill People: Conceptual and Clinical Considerations." Community Mental Health Journal 32(3): 261-74.

Nabors, L.A., M.D. Weist, R. Shugarman, M.J. Woeste, E. Mullet and L. Rosner. 2004 (July). "Assessment, Prevention, and Intervention Activities in a School-Based Program for Children Experiencing Homelessness." Behavior Modification 28(4): 565-78.

Nuttbrock, L., H. McQuistion, A. Rosenblum and S. Magura. 2003 (February). Broadening Perspectives on Mobile Medical Outreach to Homeless People." Journal of Health Care for the Poor and Underserved 14(1): 5-16.

Ontario Medical Review (OMR). 1996 (May). "Exploring the Health Impact on Homelessness." Retrieved June 23, 2008. <http://www.oma.org/phealth/homeless.htm>.

Ontario Women's Health Council (OWHC). 2002 (September). "Health Status of Homeless Women: An Inventory of Issues." Retrieved June 23, 2008. <http://www.womenshealthcouncil. on.ca/userfiles/page_attachments/library/1/Health_Status_of_Homeless_Women_EN_2047_ 695725.pdf $>$.

Plescia, M., G.R. Watts, S. Neibacher and H. Strelnick. 1997 (July). "A Multidisciplinary Health Care Outreach Team to the Homeless: The 10-Year Experience of the Montefiore Care for the Homeless Team." Family and Community Health 20(2): 58-69. 
Redlener, I. and K.B. Redlener. 1994. "System-Based Mobile Primary Pediatric Care for Homeless Children: The Anatomy of a Working Program." Bulletin of the New York Academy of Medicine 71(1): 49-57.

Reuler, J.B. 1991 (November). “Outreach Health Services for Street Youth.” Journal of Adolescent Health 12(7): 561-66.

Rog, D.J., C.S. Holupka and K.L. Combs-Thornton. 1995 (October)."Implementation of the Homeless Families Program: 1. Service Models and Preliminary Outcomes." American Journal of Orthopsychiatry 65(4): 502-13.

Roy, E., J.F. Boivin, N. Haley and N. Lemire. 1998 (July 4). "Mortality among Street Youth.” Lancet 352(9121): 32 .

Spanowicz, M.J., G. Millsap, M.J. McNamee and J.K. Bartek. 1998 (September). "Health Problems of Sheltered Homeless Men Using a Mobile Health Van: A 4-Year Study." Clinical Excellence in Nursing Practice 2(5): 279-85.

Statistics Canada. 2002 (November 5). “2001 Census: Collective Dwellings 2004.” Retrieved June 23, 2008. <http://www12.statcan.ca/english/census01/products/analytic/companion/coll/contents.cfm\#tble2 $>$.

Statistics Canada. 2008 (February 22). "Population in Collective Dwellings, by Province and Territory (2006 Census)." Retrieved June 23, 2008. < http://www40.statcan.ca/101/cst01/ famil62a.htm?sdi=collective\%20dwelling $>$.

Steele, R.W. and M.A. O’Keefe. 2001 (May). “A Program Description of Health Care Interventions for Homeless Teenagers." Clinical Pediatrics 40(5): 259-63.

Testani-Dufour, L., L. Green, R. Green and K.F. Carter. 1996. "Establishing Outreach Health Services for Homeless Persons: An Emerging Role for Nurse Managers." Journal of Community Health Nursing 13(4): 221-35.

Tischler, V., P. Vostanis, T. Bellerby and S. Cumella. 2002 (March)."Evaluation of a Mental Health Outreach Service for Homeless Families." Archives of Disease in Childhood 86(3): 158-63

Tollett, J.H. and S.P. Thomas. 1995 (December). "A Theory-Based Nursing Intervention to Instill Hope in Homeless Veterans." Advances in Nursing Science 18(2): 76-90.

United States Bureau of Primary Health Care (PCH). 1996. The Working Group on Homeless Outcomes Meeting. Rockville, MD: Author.

Wray, N.P., T.W. Weiss, T.J. Menke, P.J. Gregor, C.M. Ashton, C.E. Christian and J.C. Hollingsworth. 1999 (March). "Evaluation of the VA Mobile Clinics Demonstration Project." Journal of Healthcare Management 44(2): 133-47. 


\section{The Canadian Institutes of Health Research (CIHR)}

is a proud supporter of Healthcare Policy/Politiques de Santé.

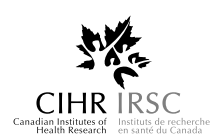

CIHR provides financial and in-kind support for the publication of Healthcare Policy/Politiques de Santé, and has played a key role in the journal's inception and development.

Longwoods Publishing gratefully acknowledges the financial support of the following organizations:

\section{CHSRF}


Saskatchewan Canadian Associazion for Health Services
and Policy Research Health Research 


\title{
Online Exclusives
}

\section{Physician Experiences Providing Primary Care to People with Disabilities}

\author{
Expérience des médecins offrant des soins de santé primaires aux \\ personnes présentant une incapacité
}

MARY ANN MCCOLL, DONNA FORSTER, S.E.D. SHORTT, DUNCAN HUNTER, JOHN DORLAND, MARSHALL GODWIN AND WALTER ROSSER

\begin{abstract}
The 2003 Statistics Canada Health Services Access Survey found that 12\% of Canadians polled did not have a family doctor, and 18\% reported access problems such as long waiting times and difficulty contacting the doctor. Research has repeatedly shown that where a problem with access exists in the general population, it is considerably more severe in subsets of the population that are most disadvantaged. Statistics at both the national and local levels confirm that although people with disabilities have greater need for health services, including both institutional and community services, they also experience significant disadvantages in attempting to access service. The question explored in this study is how physicians' perceptions of disabled patients and behaviour towards them might affect access to primary care for adults with disabilities. The study used a qualitative interpretive approach to uncover physicians' perspectives on working with people with disabilities. Semi-structured interviews were conducted with a sample of 34 physicians in Eastern Ontario. Physicians were asked:

- How are disabled patients similar to/different from non-disabled patients?

+ How are you as a physician different with disabled patients?

Physicians perceptions, as revealed by their responses to these questions, were interpreted in terms of four types of barriers to access to primary care for disabled adults: physical, attitudinal, expertise-related and systemic. These barriers were examined for their impact on finding a doctor, getting an appointment, getting into the office and receiving a reasonable standard of care.
\end{abstract}

\section{Résumé}

L'Enquête sur l'accès aux services de santé (Statistique Canada 2003) montre que 12 \% des Canadiens interrogés navait pas de médecin de famille et que $18 \%$ d'entre eux 
ont signalé des problèmes d'accès tels que les temps d'attente et la difficulté à entrer en contact avec le médecin. Les recherches ont maintes fois démontré qu'il y avait un problème d'accès pour la population en général. Ce problème est d'autant plus sévère pour les secteurs de la population les plus désavantagés. Les statistiques nationales et locales confirment que bien que les personnes présentant une incapacité ont davantage besoin de services de santé, que ce soit des services institutionnels ou communautaires, ce sont également celles qui souffrent le plus de désavantages dans l'accès aux services. La présente étude pose la question à savoir si les différences dans la perception des médecins envers les patients présentant une incapacité et si leur comportement face à ces patients mènent à des iniquités d'accès aux soins primaires pour les adultes ayant une incapacité. La méthode qualitative/interprétative a été employée pour connaître le point de vue des médecins sur leur travail avec des personnes présentant une incapacité. Des entrevues semi-structurées ont été menées auprès d'un échantillon de 34 médecins de l'Est ontarien. On leur a demandé :

- En quoi les patients présentant une incapacité sont-ils semblables ou différents des autres patients?

+ En tant que médecin, agissez-vous différemment envers les patients présentant une incapacité?

La perception des médecins, tel que le montre leurs réponses, a été interprétée en quatre types d'obstacles à l'accès aux soins primaires pour adultes présentant une incapacité : physique, psychologique, lié à l'expérience et systémique. On a étudié ces obstacles selon leur impact dans la recherche d'un médecin, dans la prise d'un rendez-vous, dans l'accès au cabinet du médecin et dans l'obtention normale de soins acceptables.

To view the full article, please visit

http://www.longwoods.com/product.php?productid $=19989$ 


\title{
Online Exclusives
}

\section{Variations in Lifetime Healthcare Costs across a Population Variation des coûts de services de santé au cours de la vie pour une population donnée}

EVELYN L. FORGET, LESLIE L. ROOS, RAISA B. DEBER AND RANDY WALLD

\begin{abstract}
The mean costs of providing healthcare increase with age, but within every age/sex cohort there is substantial variation. Moreover, this variation does not disappear over the users' lifetime. This study applies Markov modelling to administrative data to examine the variability of healthcare costs currently covered under the Canada Health Act across a population and over the lifespan. Policy initiatives that ignore individual variability across the lifespan yield inequitable results. For example, age-specific policies that exempt seniors from costs charged to the rest of the population will transfer healthcare resources to healthy low-cost seniors from younger individuals with higher needs.
\end{abstract}

\section{Résumé}

Le coût moyen de prestations de services de santé accroît avec l'âge, mais au sein de toute cohorte âge/sexe il existe des variations substantielles. Or, ces variations ne sestompent pas au cours de la vie des utilisateurs. La présente étude applique le modèle de Markov aux données administratives pour étudier la variabilité des coûts de services de santé présentement couverts par la Loi canadienne sur la santé pour une population donnée au cours de la vie de l'utilisateur. Les initiatives politiques qui ne tiennent pas compte des variabilités individuelles au cours de la vie mènent à des résultats inéquitables. Par exemple, les politiques fondées sur l'âge qui accordent aux aînés une exemption de coûts par rapport au reste de la population conduiront à un transfert des ressources en faveur d'aînés sains et peu coûteux au détriment de jeunes personnes dont les besoins sont importants.

To view the full article, please visit http://www.longwoods.com/product.php?productid $=19990$ 


\title{
Online Exclusives
}

\section{Health System Organization and Governance in Canada and} Australia: A Comparison of Historical Developments, Recent Policy Changes and Future Implications

\author{
Organisation et gouvernance des systèmes de santé au Canada et en \\ Australie : comparaison du parcours historique, des changements politiques \\ récents et des répercussions à venir \\ DONALD J. PHILIPPON AND JEFFREY BRAITHWAITE
}

\begin{abstract}
The Canadian and Australian health systems have evolved in very similar ways. Recent policy changes in each country, however, suggest a growing divergence with respect to governance. This paper traces the origins and key milestones in the evolution of governance models, with a selective focus on two provinces in Canada (Saskatchewan and Alberta) and the state of New South Wales in Australia. While divergent models seem to be manifesting, many similar underlying features remain. We assess these developments and comment on the current patterns of organization and governance, both to provide insights on future directions and to suggest what the two countries might learn from each other.
\end{abstract}

\section{Résumé}

Les systèmes de santé au Canada et en Australie ont évolué de façon similaire. Toutefois, les récents changements de politiques dans les deux pays portent à croire qu'il y a une divergence grandissante quant à la gouvernance. L'article relate les origines et les principales étapes des modèles de gouvernance respectifs des deux pays, plus précisément ceux de deux provinces canadiennes (la Saskatchewan et l'Alberta) et ceux de l'État de la Nouvelle-Galles du Sud, en Australie. Bien que les modèles semblent divergents, il existe entre eux plusieurs caractéristiques similaires. Nous évaluons leur progression et commentons les modèles d'organisation et de gouvernance actuels, à la fois pour donner un aperçu des orientations à venir et pour dégager ce que ces pays peuvent apprendre l'un de l'autre.

To view the full article, please visit http://www.longwoods.com/product.php?productid $=19991$ 


\section{GlaxoSmithKline Chair in Health Policy, Queen's Queen's University}

The Faculty of Health Sciences at Queen's University invites applications for the GlaxoSmithKline Chair in Health Policy, a tenure track position based in the Department of Community Health and Epidemiology. The Chair will provide leadership in Health Services and Policy and will hold the position of Director, Centre for Health Services and Policy Research at Queen's University. The Chair may also hold a cross-appointment in the School of Policy Studies. (see http://meds.queensu.ca/medicine/comhepi/chsprdirector.html for full description)

The Chair will devote the majority of time to an independent program of research and/or policy development in a related field. He/she will direct the Centre for Health Services and Policy Research and will provide leadership in health services and policy across the University. Teaching responsibilities will be limited, but the Chair will be expected to make some contribution to the graduate program of the Department.

Candidates should hold the requisite qualifications for an academic appointment at the level of Associate or full Professor. They should have an established track record of research productivity in the area of Health Services and Policy Research, experience in translating research into policy, a demonstrated ability to communicate effectively with faculty and students and a commitment to graduate education and supervision.

Academic rank and salary commensurate with qualifications and experience. Academic faculty at Queen's are governed by a collective agreement between the Queen's University Faculty Association and the University (posted at www.qufa.ca).

The University invites applications from all qualified individuals; however, Canadians and permanent residents will be given priority. Queen's University welcomes applications from women, visible minorities, aboriginal people, persons with disabilities, and persons of any sexual orientation or gender identity.

Please reply with cv, a description of research interests, a statement on teaching, and list of three potential referees, including names and full addresses, to:

Dr. Bill Mackillop, Department Head

Community Health and Epidemiology

Abramsky Hall, Queen's University

Kingston, Ontario, Canada, K7L 3N6 (email: william.mackillop@krcc.on.ca.)

Review of applications will commence on October 1, 2008 and continue until the position is filled. 